\title{
POJAM PRESUDIVOSTI I KANTOROWICZEV PRISTUP UTVRĐIVANJU SADRŽAJA PRAVA
}

Doc. dr. sc. Mario Krešić *

\author{
UDK: 340.131 Kantorowicz, H. \\ 340.124 Kantorowicz, $\mathrm{H}$. \\ DOI: $10.3935 /$ zpfz.69.56.05 \\ Pregledni znanstveni rad \\ Primljeno: travanj 2019.
}

Kantorowiczev pojam presudivosti u njegovoj definiciji prava upućuje na karakterističan pristup utvrđivanju sadržaja prava. Ovaj pristup može se shvatiti kao kritika pozitivizma 19. stoljeća, ali i kao pristup koji pripada teorijama kritički usmjerenima prema pravnom pozitivizmu 20. stoljeća. U ovom članku analizirat ćemo Kantorowiczev pojam presudivosti, povezati ga s njegovim širim shvaćanjem sadržaja prava te pokazati kako se na temelju pojma presudivosti može uspostaviti razlika između Kantorowiczeve teorije i obje vrste pozitivističkih teorija. Razlike u odnosu na poslijeratni pozitivizam pokazat ćemo kroz usporedbu Kantorowiczeve teorije s teorijama H. L. A. Harta i Ronalda Dworkina.

Ključne riječi: Kantorowicz, formalizam, presudivost, izvori prava, pozitivizam

\section{UVOD: FUNKCIJE DEFINICIJE PRAVA U KANTOROWICZEVOJ TEORIJI}

Herman U. Kantorowicz (1877. - 1940.) razvio je teoriju prava prema kojoj su za utvrđivanje sadržaja prava relevantne neke prakse izostavljene u drugim teorijama. Sadržaj prava odnosi se na skup pravila, a Kantorowicz razrađuje specifičnu teoriju o izvorima i interpretaciji za njihovo utvrđivanje, pri čemu

* Dr. sc. Mario Krešić, docent Pravnog fakulteta Sveučilišta u Zagrebu, Trg Republike Hrvatske 14, Zagreb; mario.kresic@pravo.hr;

ORCID ID: orcid.org/0000-0002-0014-4157 
se pravila ne mogu svesti na normativne odredbe. ${ }^{1}$ Bitan dio njegove teorije je definicija prava, koja sadržava element presudivosti. Iako su obilježja pojma prava obrađivana u nizu Kanotorowiczevih dijela ${ }^{2}$, upravo je element presudivosti u definiciji prava uveo bitan dodatak za njegovu teoriju. Kantorowicz je definiciju s elementom presudivosti prvi put uveo 1928. godine u djelu Legal science - $a$ summary of its methodology (dalje u tekstu: Legal science), a posljednja verzija takve definicije nalazi se u njegovu djelu The Definition of $L a w^{4}$, napisanom 1939. godine i objavljenom postumno 1958. godine.

Definicija prava u njegovoj teoriji prije svega ima funkciju određivanja onih obilježja prava prema kojima se ono razlikuje od ostalih normativnih pojavnosti. ${ }^{5}$ Međutim, definicija prava s elementom presudivosti ima i drugu funkciju. Ona upućuje teoretičare i praktičare koji smatraju njegovu definiciju korisnom, na određen način utvrđivanja sadržaja konkretnog pravnog poretka. Kao što i sam Kantorowicz ističe, utvrđivanje pravnog karaktera nekog pravila nije samo važno za teoriju prava nego i za pravnu praksu. ${ }^{6} \mathrm{U}$ odnosu na prvu funkciju,

1 Kantorowicz razlikuje formulirana i neformulirana pravila te navodi da se tekstualni nedostatci otklanjaju 'interpretacijom' kao praksom utvrđivanja pravila slobodnog prava. Kantorowicz, H., Legal science - a summary of its methodology, Columbia Law Review, vol. 28, br. 6, 1928., str. 692, 702. Navedena dva uvida upućuju na zaključak da Kantorowicz ne svodi pravila na normativne odredbe.

2 Zoran Pokrovac detaljno je prikazao i analizirao cjelokupan Kantorowiczev rad. Vidi Pokrovac, Z., Slobodno stvaranje prava: Herman U. Kantorowicz i slobodnopravni pokret, Naklada Breza, Zagreb, 2018.

3 Kantorowicz, op. cit. u bilj. 1.

4 Kantorowicz, H., The Definition of Law, Cambridge University Press, Cambridge, 1958.

5 Mogućnost primjene Kantorowiczeve definicije na objašnjenje pojave prava i razgraničenja prava od ostalih normativnih pojavnosti može se pronaći u: Krešić, M., Primjena Kantorowiczeve i Hartove definicije prava na međunarodno pravo, Pravni vjesnik, vol. 29, br. 3-4, 2013.; Krešić, M., Nacionalno ili međunarodno pravosuđenje kao nužan element međunarodnog prava?, Zbornik Pravnog fakulteta Sveučilišta u Rijeci, vol. 34, br. 2, 2013. U navedenim radovima sažeto je prikazana Kantorowiczeva definicija prava s obzirom na njezinu prvu funkciju kako bi se pokazala njezina korisnost za razumijevanje međunarodnog prava i utvrđivanje što međunarodno pravo čini pravom. U kontekstu navedenog cilja rada napravljena je i sažeta usporedba s Hartovom definicijom prava (pravosuđenje i identifikacija norme, norma stvaranja prava, učinkovitost). $U$ ovom radu prikaz definicije i pojma presudivosti detaljno će se analizirati i proučiti s obzirom na njezinu drugu funkciju u kontekstu utvrđivanja sadržaja prava i ispitivanja Kantorowiczeva antipozitivizma. S tim ciljem napravit će se detaljna usporedba Kantorowiczeve teorije s Hartovom i Dworkinovom teorijom, koje se smatraju suparničkim pristupima pravu.

6 Kantorowicz, H., op. cit. u bilj. 4, str. 22. Dvije funkcije definicije prava proizlaze i iz sljedećeg uvida. Dok je djelo The Definition of Law pisano 1939. godine s ciljem da 
definicija naglašava središnje mjesto pravosuđenja za razumijevanje prava i njegovo razlikovanje od ostalih normativnih pojava. S obzirom na drugu funkciju, definicija vezuje sadržaj prava uz pojam presudivosti koji, kao što ćemo vidjeti, upućuje na široki krug društvenih praksi relevantnih za sadržaj prava. Druga funkcija je tema kojom se bavimo u sljedećim poglavljima.

Teorijski problem ovog rada odnosi se na sadržaj prava, a iskazuje se u sljedećim pitanjima. Pripadaju li sadržaju prava i norme koje nije formulirao zakonodavac? Pripadaju li sadržaju prava i norme koje nisu formulirali ni zakonodavac ni sudovi? Razmišljanje o ovom problemu dominantna je tema teorije prava. Neki od ponuđenih odgovora na postavljena pitanja oblikovani su i kao kritika pozitivizma koja se pojavila prije i nakon Drugog svjetskog rata. Praktični problem koji se nadovezuje na rješavanje teorijskog problema odnosi se na utjecaj različitog shvaćanja prava na praksu utvrđivanja konkretnog sadržaja nekog pravnog poretka.

Odgovore na teorijska pitanje istražit ćemo na temelju interpretacije Kantorowiczeve teorije. Njegove pojmove ćemo analizirati uzimajući u obzir uvide drugih autora koji su isticali važnost pravosuđenja za pravo kao što su H. L. A. Hart, Ronald Dworkin, Alf Ross, Joseph Raz i John W. Salmond. Odrednice za razmišljanje o praktičnom problemu naznačit ćemo u zaključku upućivanjem na neke moguće posljedice prihvaćanja Kantorowiczeva shvaćanja prava za praksu.

Nakon uvoda, analizirat ćemo Kantorowiczevu definiciju prava (2. poglavlje), zatim zasebno element presudivosti u njegovoj definiciji (3. poglavlje), koji ćemo povezati s njegovim shvaćanjem sadržaja prava (4. poglavlje). Nakon toga ćemo objasniti u čemu bi se mogla sastojati njegova kritika pozitivizma (5. poglavlje) te zaključno utvrditi teorijske i naznačiti praktične posljedice njegova shvaćanja prava (6. poglavlje).

\section{2. ŠTO JE PRAVO?}

U djelu The Definition of Law Kantorowicz je postavio sljedeću stipulativnu definiciju prava. Pravo je "skup društvenih pravila koja propisuju vanjsko ponašanje i koja se smatraju presudivima". ${ }^{7} \mathrm{U}$ ovakvoj definiciji možemo razlučiti četiri elementa: a) skup društvenih pravila; b) pravila koja propisuju kako se

se pruži teorijski okvir za pregled pravne znanosti, djelo Legal science iz 1928. godine navodi istu definiciju prije izlaganja o izvorima prava.

7 Kantorowicz, op. cit. u bilj. 4, str. 79: "Using it thus, we can give our definition a more concise and final form by proposing to call law 'a body of social rules prescribing external conduct and considered justiciable'." 
treba ponašati; c) pravila koja reguliraju vanjsko ponašanje; d) pravila koja se smatraju presudivima. ${ }^{8}$

Prije analize njezinih elemenata možemo primijetiti da Kantorowiczeva definicija ne sadržava izričito element učinkovitosti. On se protivi ograničenju pojma prava samo na pravila koja su učinkovita u praksi službenih organa. Iz pogleda na prvu funkciju definicije, takvo bi ograničenje isključilo iz sistematizacije pravnih poredaka one pravne sustave koji više nisu učinkoviti kao što je primjerice rimsko pravo $^{9}$, odnosno iz pogleda na njezinu drugu funkciju iz sadržaja prava bi se isključila pravila koja nisu učinkovita. Takva se redukcija može izbjeći uz istodobno zadržavanje uobičajenog shvaćanja pravnog sustava, ako značenje izraza 'smatrati presudivim' stavimo u vremenski kontekst tako da se pojmom prava obuhvate i norme koje su bile smatrane presudivima u nekom povijesnom trenutku. Štoviše, ako se pravila nekog prošlog pravnog sustava i dalje smatraju presudivima u zajednici, ona pripadaju sadržaju prava takve zajednice.

(1) Sukladno prvom elementu definicije vidimo da Kantorowicz pod pojmom prava smatra skup pravila. Iako su činjenice bitne za razumijevanje prava, pravo je nemoguće spoznati bez normativnog aspekta prava. U tom smislu on odbacuje tezu prema kojoj "pravo nije skup pravila, nije trebanje, nego činjenična stvarnost". ${ }^{10}$ Ovu tezu Kantorowicz pripisuje nekim predstavnicima američkog realizma. Nadalje, kod utvrđivanja koja društvena pravila pripadaju pravu Kantorowicz odbacuje kriterije kao što su "pozitivnost, provedivost, državno podrijetlo, obvezujući karakter". ${ }^{11}$ To nas upućuje prema shvaćanju da on ne smatra pravom samo sustav normi koje je proizveo zakonodavac ovlašten drugom normom tog sustava. Pod sadržaj prava bi se mogla svrstati i ona društvena pravila koja nije proizveo zakonodavac, pod uvjetom da su zadovoljeni ostali uvjeti definicije.

(2) Drugi element je izraz široko prihvaćenog stava u teoriji prava da pravo regulira ponašanje osoba. Pri tome, navođenje 'propisivanja' u Kantorowiczevoj definiciji primarno nas upućuje na shvaćanje prava kao sustava normi kojima

8 Hart je uputio tri kritike sadržaju Kantorowiczeve definicije prava: nedovoljno objašnjenje značenja pravila, nejasno značenje izraza 'smatrano presudivim' i ograničenje prava na "vanjsko ponašanje”. Hart, H. L. A., Review: The Definition of Law by Hermann Kantorowicz; A. H. Campbell; A. L. Goodhart, The Philosophical Review, vol. 69, br. 2, 1960., str. $270-272$.

$9 \quad$ Ibid., str. 16.

10 Kantorowicz, H., Some Rationalism about Realism, The Yale Law Journal, vol. 43, br. 8, 1934., str. 1243. Kantorowicz ne pravi izričito razliku između normi i pravila, pa je u ovom radu takva razlika zanemarena. Jedna od Hartovih primjedbi je upravo nedovoljno objašnjenje pojma pravila. Vidi bilješku 8.

11 Kantorowicz, op. cit. u bilj. 4, str. 13. 
se zabranjuje ili zapovijeda ponašanje. Prema Kantorowiczu pravila se najbolje mogu izraziti kao zapovijedi (pri čemu se zabrane mogu svesti na zapovijedi) iako se zbog jezičnih ili tehničkih razloga mogu prikazati kao pravila ovlašćivanja ili dopuštanja. ${ }^{12}$

(3) Treći element usmjerava nas prema zaključku da se pravo bavi izvanjskim ponašanjem, a ne unutarnjim procesima u subjektu. Drugim riječima, pravom se može propisati što netko ne bi trebao govoriti, ali se ne može propisati što bi netko trebao misliti.

(4) Četvrti element koji ćemo detaljno obraditi u sljedećem poglavlju upućuje na Kantorowiczev poseban pogled na pravo. Naime, prvi i četvrti element zajedno označavaju pravo kao 'skup društvenih pravila koja se smatraju presudivima'. Ovakvo shvaćanje prava navodi nas na propitivanje najprije Kantorowiczeve antiformalističke pozicije, a zatim i pozicije koja bi mogla biti suprotstavljena poslijeratnom pozitivizmu.

\section{POJAM PRESUDIVOSTI}

Određenje obilježja presudivosti nekog pravila presudno je za razumijevanje Kantorowiczeve teorije prava te za posljedice koje ono ima za utvrđivanje sadržaja prava. Različita određenja presudivosti daju različite odgovore na niz pitanja. Je li za pojam presudivosti pravila presudno mišljenje zakonodavca ili je jednako važno što misle suci? Je li dovoljno pojam proširiti na suce ili pojam obuhvaća i ostale subjekte koji tvrde da neko pravilo ima obilježje presudivosti? Može li pravilo koje sudovi trenutačno ne smatraju presudivima ipak biti presudivo? Kako testirati koje je pravilo presudivo i sukladno takvom testu napraviti razliku između pravnog i nepravnog pravila?

Kantorowicz nije do kraja razjasnio pojam presudivosti, ali znamo da je izraz preuzeo iz javnog međunarodnog prava te ga prilagodio svojoj teoriji prava. Takva prilagodba pojma presudivosti omogućuje njezinu primjenu na utvrđivanje sadržaja prava i napuštanje rasprave o prirodnoj razlici između pravnih i političkih sporova koju neki teoretičari smatraju neopravdanom. ${ }^{13} \mathrm{U}$ nastavku ovog poglavlja izložit ćemo obilježja presudivosti grupirana u dvije kategorije: formalna (koja doprinose razgraničenju pravnih od nepravnih pravila, ali ne utječu na konkretan sadržaj pravila) i materijalna (koja utječu na konkretan sadržaj pravila u nekom poretku) obilježja.

12 Ibid., str. 40.

13 Vidi primjerice Lauterpacht, H., The Function of Law in the International Community,

The Lawbook Exchange, New Jersey, 2000. 


\subsection{Formalno određenje presudivog pravila: postojanje pravosuđenja i općenitost pravila}

Uvođenjem pojma presudivosti u svoju teoriju prava Kantorowicz jasno vezuje pojam prava uz pojam pravosuđenja. S jedne strane, postojanje pravosuđenja čini razlikovno obilježje u odnosu na ostale normativne sustave, dok s druge strane ono predstavlja pojmovni element koji je bitan za utvrđivanje sadržaja prava. Naime, prema Kantorowiczu presudivost je obilježje koje neko pravilo mora imati da bi bilo pravno, a prije svega to znači mogućnost da se ono može predložiti nekom sudbenom organu radi njegove primjene u postupku koji ima određena obilježja. ${ }^{14}$ Postojanje organa i postupka kao uvjeta postojanja pravnog pravila možemo podvesti pod zajednički nazivnik postojanja pravosuđenja.

Kantorowicz shvaća pojam organa pravosuđenja u njegovu ne-tehničkom značenju ${ }^{15}$, prema kojem za njegovo određenje nije bitan sastav organa, na koji način se sastavlja i koje sve ostale nadležnosti obavlja. Kao primjere takvog organa Kantorowicz uz državne suce navodi starješine, poglavice, vračeve, svećenike, mudrace, proroke, vijeća plemenskih staraca, sportske suce, arbitre, crkvene sudove, sudove ljubavi, sudove časti, čak i vođe bandi. ${ }^{16}$ Budući da je koncept sudskog organa ovako široko shvaćen, postojanje pravosuđenja mora se utvrditi na drukčiji način: svođenjem organa na autoritet i detaljnijim određenjem postupka.

Kantorowicz svodi sudski organ na "konačni autoritet koji se bavi nekom vrstom 'kazuistike', to jest primjenom načela na pojedinačne slučajeve konflikata između stranaka". ${ }^{17}$ Pri tome, vezano uz pojam pravosuđenja on uvodi i pojam konačnosti, pripisujući mu dva značenja: formaliziranost postupka i neodređenost pravila. ${ }^{18}$ Iz Kantorowiczevih uvida o pravosuđenju vidimo da je riječ o postupku u kojem: a) odlučuje konačni autoritet, b) primjenom općih pravila na pojedine slučajeve, c) u formalnom i konačnom postupku, d) kako bi riješio spor oko primjene neodređenih pravila.

Pojam konačnog autoriteta upućuje na postavku o institucionalnosti prava u smislu prihvaćanja normi ovlašćivanja organa za donošenje odluka koje se

\footnotetext{
14 Kantorowicz, op. cit. u bilj. 4, str. 79: "[...] justiciable will here be applied to rules which are considered fit to be applied by a judicial organ in some definite procedure".

15 Ibid., str. 80.

16 Ibid., str. 83.

17 Ibid., str. 69.

18 Ibid., str. 75 - 76 .
} 
poštuju.$^{19}$ Slično, u suvremenoj pravnoj teoriji, teoretičari poput Raza smatraju da je neki normativni sustav pravni sustav samo ako zahtijeva da je autoritativan i da zauzima mjesto supremacije unutar društva. ${ }^{20}$ Za postojanje pravosuđenja Kantorowiczu je dovoljno da se organ pravosuđenja koji vodi odgovarajući postupak prihvati unutar grupe u kojoj postoji pravilo koje bi se trebalo primijeniti. ${ }^{21} \mathrm{~S}$ obzirom na to da se odluka donosi konačno za spor između dvije strane, autoritet odlučivanja nužno mora biti treća strana u postupku. ${ }^{22}$ Prema tome, presudivo je samo ono pravilo o kojem može odlučivati konačni autoritet kao treća strana.

Iz Kantorowiczeva shvaćanja pravosuđenja proizlazi da pravilo mora biti opće da bi se smatralo presudivim pravilom. Pretpostavka da sudovi utemeljuju svoje odluke na općim pravilima opće je prihvaćeno u teoriji prava, iako intuitivnost takvog uvida zahtijeva dodatno opravdanje. Naime, možemo zamisliti sudsku praksu koja se sastoji od donošenja ad hoc odluka koje nisu utemeljene na općim pravilima. ${ }^{23}$ Salmond navodi sljedeće argumente u prilog tezi da bi čak i u tom slučaju došlo do odlučivanja na temelju općih pravila. Najprije ističe da bi takva praksa mogla uključivati takvo shvaćanje pravednosti koje pretpostavlja pravila i odudara od "sustava slobodne sudske diskrecije". ${ }^{24}$ Nadalje, Salmond napominje da bi čak i u tom slučaju sudovi s vremenom počeli primjenjivati pravila. Sud koji početno sudi "prema pravdi” teži svoje odluke utemeljiti na općim standardima pod uvjetom da je riječ o stalnoj funkciji. Prema Salmondu transformacija 'pravosuđenja na temelju osjećaja pravednosti' prema 'pravosuđenju sukladno pravu' događa se iz praktičnih razloga. Samo kad se dogodi takav prijelaz u sudskoj praksi, možemo smatrati da se "pravo sastoji od pravila prepoznatih i primijenjenih od sudova". ${ }^{25}$

Zaključno, na temelju onoga što je dosad izneseno, presudiva su samo opća pravila o kojima može odlučivati konačan autoritet kao treća strana. Preostaje nam razmotriti formalno određenje presudivosti pravila s obzirom na obilježja formalnosti postupka i neodređenosti pravila.

19 Ibid., str. 70.

20 Raz, J., The Authority of Law, Oxford University Press, New York, 1979., str. 43.

${ }^{21}$ Kantorowicz, op. cit. u bilj. 4, str. 70.

22 Ibid., str. 72.

23 "A tribunal in which conscience and natural justice are excluded by no rigid and artificial rules, in which the judge does that which he deems just in the particular case, regardless of general principles, may not be an efficient or trustworthy tribunal, but is a perfectly possible one. It is a court of justice which is not also a court of law." Salmond, J., Jurisprudence, Sweet \& Maxwell, London, 1930., str. 44.

Ibid., str. 45.

Ibid., str. 39. 


\subsection{Formalno određenje presudivog pravila: formalnost postupka $i$ neodređenost pravila}

Kao što smo naveli, Kantorowicz koristi obilježje određenosti (definitiveness) u njegova dva značenja: određenost postupka i (ne)određenost pravila. Određenost postupka znači da su radnje postupka unaprijed uređene i utvrđene pravilima kako bi dovele do konačne odluke. Ovaj tip određenosti može se zamijeniti nazivom 'formalnost' postupka. ${ }^{26}$ Obilježje određenosti pravila odnosi se na njihov detaljno određen i nesporan sadržaj zbog čega se njihova primjena čini nespornom, a ako bi se i dogodilo da neki autoritet odlučuje o njihovoj primjeni, nema potrebe da se takva odluka donosi pred sudskim organom. ${ }^{27}$

U kontekstu neodređenosti pravila Kantorowicz pravi razliku između običaja koji nisu pravna pravila i pravnih pravila. "Karakteristična osobina velike većine običaja jest da su esencijalno izvorno nesporni. Ali određeni običaji, posebno oni kojima se namjeravaju kontrolirati individualni ekonomski interesi ili pretjerane seksualne strasti, vode u konflikte između članova iste zajednice i prema tome upućuju na rješavanje od nepristranih autoriteta u nekom redovnom postupku, s ciljem da se spriječe slični konflikti u budućnosti”. ${ }^{28} \mathrm{Na}$ istom tragu, Kantorowicz se osvrće na pravila učtivosti u nekom društvu. Ta pravila "rijetko vode prema konfliktu između pojedinaca (što je to rjeđe, to su više konačna) i prema tome rijetko pozivaju na odluku sudbenog organa, ako treba postojati takav autoritet. Čak i u tim slučajevima poredak i karakter postupka ne bi bili određeni u smislu kako je upravo indicirano". ${ }^{29}$

$\mathrm{Na}$ temelju svih četiriju navedenih formalnih određenja presudivog pravila možemo zaključiti da pravilo ima obilježje presudivosti ako o njemu može odlučivati treća strana kao konačan autoritet u konačnom i formaliziranom postupku, ako je opće i ako postoji mogućnost spora oko njegove primjene koji je takvog karaktera da zahtijeva razrješenje spora od autoriteta kao treće strane u formaliziranom i konačnom postupku. Iako ovakva formalna određenja presudivosti sužavaju područje presudivih pravila, i dalje ostaje značajna neodređenost što bi se moglo smatrati presudivim pravilom u nekoj zajednici.

26 Ibid., str. 74.

27 Ibid., str. 75.

28 Kantorowicz, op. cit. u bilj. 4, str. 76.

29 Ibid., str. 75. Ovakvo shvaćanje upućuje na određenu sličnost s Hartovim razlikovanjem pravila od navika. Prema Hartu pravila imaju unutarnji aspekt koji se očituje u kritičkom stavu prema određenom obrascu ponašanja kao zajedničkom standardu. Hart, H. L. A., The Concept of Law, Oxford University Press, New York, 1994., str. 57. 


\subsection{Materijalno određenje presudivog pravila: subjekti i društvene okolnosti}

Dodatno određenje pojma presudivosti može se potražiti u odgovoru na pitanje koje sve subjekte Kantorowicz smatra pravno relevantnim za utvrđivanje presudivosti pravila?

Iako je često kritiziran da želi istisnuti zakonodavca iz odlučivanja o pravu, Kantorowicz nikada nije zastupao takvu tezu. Nasuprot tome, on kritizira preuveličavanje teze o slobodnom pravu od strane "onih realista koji poučavaju da se pravo sastoji samo i jedino od sudskih odluka, te stoga iz činjenica". ${ }^{30}$

U pojašnjenjima svojih stavova o zakonodavstvu, za koja se može tvrditi da su korigirana u odnosu na početne stavove, upućivao je na primarnu ulogu zakonodavca. ${ }^{31}$ Nadalje, kao što smo već naveli, iz cjelokupne Kantorowiczeve teorije proizlazi središnje mjesto sudova za pojam prava i nema sumnje da sudovi imaju i središnje mjesto kod utvrđivanja presudivih pravila. Pri tome možemo ponoviti da on sudski organ određuje na način da uključuje različite osobe i tijela u situacijama kad provode postupak pravosuđenja.

Međutim, Kantorowicz se nije zaustavio samo na mišljenju zakonodavca i sudaca kod određenja presudivosti pravila. Za presudivost pravila važno je i što misle ostali "koji stvarno primjenjuju pravila ili žele da se pravila primijene". ${ }^{32}$ Takav stav o širem krugu osoba koje utječu na utvrđivanje presudivih pravila proizlazi i iz njegova stava da pravila ne moraju biti ni formalno ozakonjena ni stvarno primijenjena od sudova da bila pravna pravila te da definiciju prava ne treba isključivo vezivati uz pravila koja potječu od države. ${ }^{33} \mathrm{U}$ tom smislu, primjerice, pravni znanstvenici imaju važnu ulogu za utvrđivanje presudivosti pravila. $^{34}$

Važnost stavova o utvrđivanju presudivosti pravila koja nisu proizvod odluka službenih osoba o tome što je obvezujuće pravilo vidljivo je kod Kantorowicza u sljedećim primjerima. Pravila koja možda neće biti podvrgnuta odlučivanju u sudskim postupcima još uvijek će biti pravo ako su "tako blisko povezana s pravilima nedvojbenoga pravnog karaktera da moraju biti, i doista uvijek

30 Kantorowicz, op. cit. u bilj. 10, str. 1241. Ovaj rad će "kasnije biti ocijenjen kao važan doprinos ograničavanju utjecaja realističke pravne teorije u SAD-u". Pokrovac, op. cit. u bilj. 2, str. 735 .

31 Pokrovac, op. cit. u bilj. 2, str. 291.

32 Kantorowicz, op. cit. u bilj. 4, str. 73.

33 Ibid., str. 12, 13.

34 Vidi Pokrovac, op. cit. u bilj. 2, str. 120. 
jesu, tretirana zajedno s njima $\mathrm{u}$ istim knjigama, ili u istim zakonima, od istih pravnika, od istih pravnih metoda, i prema tome moraju se smatrati pravom". 35 Neka pravila de lege ferenda, kao što su nacrti zakona, također su pravo jer su "često predmet literature znanstvene vrijednosti i metodološki istog karaktera kao knjige o pravu koje je na snazi” ${ }^{36}$ Iako ovakvi primjeri upućuju na znanstveno određenje sadržaja prava, vidjet ćemo u nastavku da neslužbeno pravo nije ograničeno samo na znanstvenike.

$\mathrm{Na}$ daljnje određenje subjekata izvan državnih institucija koji utječu na utvrđivanje presudivosti pravila upućuje nas Kantorowiczev stav da to ne mogu biti pravni i društveni filozofi koji ne govore o primjeni postojećeg prava, nego iznose radikalne programe za, primjerice, njegovo ukidanje. ${ }^{37}$ Budući da njihovi stavovi nisu stavovi o tome što se smatra sadržajem postojećeg prava, pravila koja predlažu nisu presudiva pravila.

$\mathrm{Na}$ istom tragu mogli bismo dopuniti Kantorowicza. Utvrđivanje konkretnog sadržaja prava ovisi o životu konkretne zajednice, a ne o apstraktnim stavovima koji bi vrijedili za sve pravne poretke nevezano o stvarnim društvenim praksama. Dok se filozofi prava mogu baviti pravom na način koji nema utjecaj na sadržaj konkretnog pravnog poretka, posebna uloga pravnih znanstvenika kod utvrđivanja sadržaja prava proizlazi iz pretpostavke drukčijih obilježja njihove prakse. Ona je obilježena nastojanjem da se riješe pravni problemi postojećim pravom, pri čemu je važno da su njihova mišljenja o sadržaju prava podržana odgovarajućim stvarnim okolnostima u zajednici. Ovaj posljednji uvid nas vodi prema društvenoj uvjetovanosti sadržaja prava. Prihvaćajući tezu povijesnopravne škole, pravo je prema Kantorowiczu uvijek postavljeno i neka realnost (moć, volja, priznanje) mora podržavati pravna pravila. ${ }^{38}$ Drugim riječima, presudivost pravila u zajednici ovisi o njihovoj prihvaćenosti od pripadnika te zajednice.

Na temelju iznesenih uvida može se reći da se presudivost pravila utvrđuje: pravom institucionaliziranim praksama za odlučivanje o pravu, praksama koje

35 Kantorowicz, op. cit. u bilj. 4, str. 72.

36 Ibid.

37 Ibid., str. 73.

38 "For in contrast to earlier legal philosophies that believed that there was a law validated by nature, the main proposition of the Historical School, as already mentioned, is that all law is positive, and therefore law exists if and only if some reality (power, will, recognition) supports the legal proposition." Kantorowicz, H., The Battle for Legal Science (prijevod C. Merill), German Law Journal, vol. 12, br. 11, 2011. (prvo izdanje u Njemačkoj 1906.), str. 2009. Engleski prijevod za 'Rechtssatz' je 'legal proposition'. Oba se izraza mogu prevesti kao 'pravilo', uz napomenu da Rechtssatz i legal proposition mogu imati više značenja. 
nisu institucionalizirane na taj način, pri čemu posebno mjesto zauzima praksa pravnih znanstvenika, te relevantnim praksama pripadnika dijela ili čitave zajednice u kojoj se utvrđuje presudivost pravila. Nadalje, budući da se takve prakse provode na različite načine $u$ različitim zajednicama, sam sadržaj prava će se razlikovati od zajednice do zajednice, odnosno i unutar same zajednice ovisno o društvenim okolnostima.

\section{POJAM PRESUDIVOSTI I SADRŽAJ PRAVA}

Prethodno određenje pojma presudivosti može se potkrijepiti ostalim Kantorwiczevim razmišljanjima o sadržaju prava. Povezivanje stavova o presudivosti i sadržaju prava doprinosi potpunijoj slici Kantorowiczeva pojma prava i važnosti samog pojma za utvrđivanje sadržaja prava u konkretnim pravnim porecima.

Prema Kantorowiczu, u svakom pravnom poretku razlikuje se slobodno i zakonodavno pravo, a slobodno pravo dijeli se na individualno pravo i pravo zajednice. ${ }^{39}$ Kantorowicz opisuje vrste slobodnog prava na sljedeći način. Razlika između njih temelji se na činjenici o tome je li pojedinac prihvatio pravilo na temelju svojih vlastitih uvjerenja ili na temelju uvjerenja zajednice. Pri tome, isto se pravilo može pojaviti kao pravilo zakonodavnog prava, slobodnog individualnog prava ili slobodnog prava zajednice. Ne ulazeći u razjašnjavanje razlike između individualnog slobodnog prava i slobodnog prava zajednice, Kantorowicz ipak navodi da je prvo značajnije za pravnu znanost, dok je drugo važnije za pravosuđenje, dodajući da je slobodno pravo zajednice u bliskoj vezi s običajnim pravom. ${ }^{40}$ Prema Kantorowiczu, slobodno pravo je pravo koje se dohvaća i bez uvida u zakone. Stranac u nekoj tuđoj zemlji ne može spoznati jezik, povijest, umjetnost, tradiciju samo iz zakona. Takva spoznaja, kao i spoznaja slobodnog prava, može se postići samo živeći u takvoj zajednici. Slobodno pravo postoji neovisno o zakonodavnom, ali zakonodavno ne može postojati neovisno o slobodnom pravu. Kritika zakonodavnog prava i popunjavanje pravnih praznina temelji se na pravilima koja su oblikovana kroz slobodno pravo. ${ }^{41}$

39 Ibid., str. 2009.

40 Ibid.

${ }^{41}$ Ibid., str. 2010: "All criticism of statutory law, the very means by which it develops further, must by definition be drawn on the basis of free law (which, for the critic, foreign statutory laws also belong to)." Ibid. Kantorowicz ne određuje tko kritizira zakonodavstvo, pa možemo zaključiti da kritika može doći od strane svih subjekata relevantnih za pravo. 
Kantorowicz nadalje pravi razliku s obzirom na važenje različitih oblika prava. Društvena pravila koja ne potječu od zakona i pravnim poretkom dopuštenih običaja ne vrijede za suce na isti način kao ta dva oblika prava. ${ }^{42} \mathrm{Na}$ tom tragu Kantorowiczeva uzimanja u obzir specifične uloge važenja državnog prava za praksu sudaca i sukladno opisu prava iznesenom u Definiciji, može se reći da je obilježje presudivosti raznih društvenih pravila stvar stupnja, pri čemu pravila koja potječu od zakona imaju (ili bolje rečeno mogu imati) viši stupanj presudivosti od pravila iz nekih drugih izvora.

U prilog tezi o stupnjevitosti presudivosti ide i njegov prikaz vrsta izvora prava iznesenih u Legal science odmah nakon definicije prava. Među takvim izvorima razlikuju se: a) izvori koji su prošli i završili proces formiranja i izvori koji nisu završili taj proces, b) izvori koji su oblikovani praksom zakonodavaca, sudaca i pravnih običaja, c) nastali izvori, izvori u nastanku i izvori koji su željeno pravo te d) eksplicitni i implicitni izvori. ${ }^{43}$ Pri tome, možemo reći da bez obzira na stupanj realiteta ne postoje društvena pravila koja su prema svojoj prirodi nepresudiva, već je to određeno shvaćanjem pojma presudivosti te formalnih i materijalnih ograničenja presudivosti. Takvo objašnjenje stupnjevitosti presudivosti odgovara Kantorowiczevu viđenju 'stupnjeva realiteta'. ${ }^{44} \mathrm{Na}$ tom tragu shvaćanja sadržaja prava je i Alf Ross kada govori o različitim stupnjevima pojavnosti izvora prava, pri čemu ne treba zaboraviti da je Ross proučavao slobodnopravne teorije i priznao njihov doprinos razumijevanju izvora prava. ${ }^{45}$ Ipak, za razliku od Rossa, Kantorowicz smatra pravilima trenutačnog poretka i ona pravila koja nemaju potvrdu u trenutačnoj 'normativnoj ideologiji ${ }^{46}$ sudaca ako se mogu smatrati presudivima u nekoj zajednici.

Kantorowiczevo shvaćanje sadržaja prava potvrđuje naprijed izneseno viđenje njegova pojma presudivosti. Kantorowicz pod pojam prava svrstava zakone te običaje kad su u pravnim porecima smatrani presudivima, ali isto tako i ostala

42 Kantorowicz u svojoj kritici Savignya upozorava na razliku između izvora valjanosti (la source de la valeur) i izvora sadržaja (la source du contenu). Kantorowicz, H., Qu' est pour nous Savigny?, traduction français par Georges Bonnet, Paris, M. Girard \& E. Brièr, 1914. O razlici između izvora pravnog važenja i izvora pravnog sadržaja koje je Kantorowicz iznio u Was ist uns Savigny?, Berlin, Heymann, 1912., vidi Pokrovac, op. cit. u bilj. 2, str. 239.

43 Kantorowicz, op. cit. u bilj. 1, str. $693-792$.

44 O stupnjevima realiteta vidi Pokrovac, op. cit. u bilj. 2, str. 206.

45 Ross, A, On Law and Justice, Lawbook Exchange, New Jersey, 2004., str. 156.

46 Prema Alfu Rossu normativna ideologija sudaca odnosi se na stvarno postojeću ideologiju sudaca u nekom poretku o izvorima prava i ideologiju metode (interpretacije). Ibid., str. 74, 75, 109. 
pravila koja su proizvod praksi relevantnih za pravo kao što su, primjerice, pravna znanost ${ }^{47}$, sudsko pravo ili izrada nacrta zakona. Pri tome Pokrovac svrstava Kantorowiczevo poimanje sadržaja prava u nekonvencionalne pravne teorije. "Luhmann jasno pokazuje da je sam pojam izvora zapravo samo metafora koja služi odlučivanju o tome što će biti uključeno odnosno isključeno u pojam važenja, koji sam biva utemeljen onom metaforom". ${ }^{48}$ Prema Niklasu Luhmannu kontekst primjene metafore, kao figure obrazloženja, leži u odlukama o primjeni prava, tj. u pitanju “je li pravo, na koje se pozivamo, s pravom uzeto kao važeće”. ${ }^{49}$ Pokrovac, slijedeći Luhmanna, nekonvencionalnim mišljenjima (među koje svrstava i slobodnopravne koncepcije izvora prava) pripisuje legitimnost na temelju postojanja "općeg pojma izvora prava, koji omogućava barem minimalnu koordinaciju različitih stavova o izvorima". ${ }^{50}$ Čini se očitim da nekonvencionalni pristup vodi prema kritici formalizma. Međutim, ovakva nekonvencionalnost koja stvara određene razlike $\mathrm{u}$ odnosu na Hartove stavove podsjeća i na Dworkinov pogled na pravo. Te naznake o odnosu prema pozitivizmu uvod su u sljedeće poglavlje.

\section{KANTOROWICZEVA KRITIKA PRAVNOG POZITIVIZMA}

Pokrovac svrstava Kantorowiczeva gledišta među kritičke teorije koje vodi ambicija otkrivanja nedostataka pravnog pozitivizma. ${ }^{51}$ Otklon od pozitivizma otvoreno izražava i sam Kantorowicz kada svoju teoriju naziva prirodnim pravom 20. stoljeća. 'Prirodnopravna narav' njegove teorije očituje se u tezi da pozitivno pravo proizlazi iz slobodnog prava, koje nije pozitivno u smislu da ga je postavio zakonodavac, a kao što ćemo pokazati u nastavku, ne mora biti ni pozitivno u smislu da ga je postavio sudac. Ipak, za razliku od tradicionalnih prirodnopravnih teorija, Kantorowicz smatra da je svako pravo, uključujući i slobodno pravo, pozitivno u sljedećem smislu. Pozitivnost za njega znači da pravo odnosno pravna pravila uvijek podržava moć, volja i priznanje. ${ }^{52}$ Postojeće kritike pozitivizma, za potrebe ovog rada, mogu se podijeliti na razdoblja prije i nakon Drugog svjetskog rata.

47 Kantorowicz prihvaća da je pravna znanost izvor prava i prestaje "biti spoznavanje spoznatoga”. Kantorowicz, op. cit. u bilj. 38, str. 2013.

48 Pokrovac, op. cit. u bilj. 2, str. 242.

49 Ibid.

50 Ibid.

51 Ibid., str. 385.

52 Kantorowicz, op. cit. u bilj. 38, str. 2009. 


\subsection{Kantorowicz i kritika prijeratnog pozitivizma}

Jedna od kritika pozitivizma u prvom razdoblju pozitivnopravne tradicije rezultat je nezadovoljstva formalizmom koji se vidio kao posljedica ili odraz takvog pozitivizma. ${ }^{53}$ Pod nazivom ‘teorijski pozitivizam’ ovog razdoblja Barberis svrstava teorije koje sadržavaju neke od sljedećih teza: a) nema prava izvan pozitivnog prava; b) pozitivno pravo služi upravljanju ponašanja pomoću zapovijedi ili normi praćenih sankcijama; c) pravne norme stvorene su od države i deduktivno primjenjive od sudaca; d) pravo je uređen sustav normi; e) pravni sustav ima obilježja jedinstvenosti, koherentnosti i potpunosti; f) pravna dogmatika je izvorna znanost o pravu. ${ }^{54}$ Barberis primjećuje da je antiformalistička struja pravne misli usmjerena na kritiku stavova pravnog pozitivizma 19. stoljeća o "izvorima prava (postavljajući apsolutno središnje mjesto zakonima), ispravnoj ulozi sudaca kao tumača zakona (uloga koje se reducira na jednostavnu primjenu zakona) i načinima na koji se pravni pojmovi konstruiraju (na temelju Jheringove metode), čime se pravo potpuno odvojilo od stvarnosti". ${ }^{55}$ Slično tome, Viola smatra da je zajedničko obilježje antiformalističkih teorija usmjerenost na rješavanje problema podrijetla i svrhe prava, izvora prava te tumačenja i primjene pozitivnog prava. ${ }^{56}$ Takvi prikazi povijesti teorije prava pokazuju da je utvrđivanje sadržaja prava središnja tema kojom se bavi kritika pozitivizma ovog razdoblja. Barberis i Viola svrstavaju pripadnike slobodnopravnog pokreta $\mathrm{u}$ antiformalistički tabor jer se bave problemima pozitivizma. Među takvim problemima je, primjerice, neizvjesnost (uncertainty) "koja proizlazi iz prepoznavanja odgovarajuće pozitivne norme zato što teorije o pravnom važenju [legal validity] nisu jednoglasne i zato što se konkretni slučajevi ne mogu svrstati unutar nedvosmislenih kategorija". ${ }^{57}$

Polazeći od navedenih odrednica antiformalističkih teorija i na temelju prethodnog opisa pojma presudivosti, prema kojem se pravo ne temelji isključivo na normama postavljenima od zakonodavca, Kantorowicza možemo svrstati u protivnike pozitivizma 19. stoljeća. Pri tome njegov antiformalizam ne znači napuštanje normativnog aspekta prava i odbacivanje vezanosti suca za zakone.

53 Viola, F., Introduction: Natural Law Theories in the 20th Century, u: Pattaro, E.; Roversi, C. (ur.), Legal Philosophy in the Twentieth Century: The Civil Law World, Springer, Netherlands, 2016., (dalje u tekstu: LP), II. svezak, str. 49.

54 Barberis, M., Introduction: Legal Positivism in the 20th Century, u: LP, II. svezak, str. 181.

55 Ibid., str. 188.

56 Viola, op. cit. u bilj. 53, str. 25.

57 Ibid., str. 35. 
Prethodno smo upozorili na njegovu kritiku nekih pripadnika američkog realizma koji, prema Kantorowiczu, svode prava samo na činjenice o aktivnostima sudova i na njegove stavove o mogućoj presudnoj ulozi zakona za praksu sudova. $\mathrm{S}$ druge strane, $\mathrm{u}$ prethodnim poglavljima pokazali smo da se Kantorowicz ne zadovoljava ublažavanjem pozitivističkog ograničenja sadržaja prava samo kroz dodavanje sudske prakse kao prakse relevantne za utvrđivanje takvog sadržaja. Ova tema vodi prema sljedećem potpoglavlju.

\subsection{Kantorowicz i kritika poslijeratnog pozitivizma}

Kritika pozitivizma nakon Drugog svjetskog rata najčešće se predstavlja u svjetlu rasprave o odnosu prava i morala kojoj su okvir zadale Hartova teorija prava i kritike njegove teorije. ${ }^{58}$ Najznačajnije kritike pozitivizma su Dworkinov konstitucionalizam i kontinentalni neokonstitucionalizam. ${ }^{59}$ Iako se odnos morala i prava čini najistaknutijom temom ovog razdoblja, u pozadini rasprave je razilaženje oko ostalih tema, među kojima su izvori prava i razlikovanje prava od ostalih područja društvenog života. Usmjerenost na ta pitanja omogućuje promišljanje o Kantorowiczevoj teoriji u kontekstu rasprava nastalih nakon njegova života.

Kao što smo prethodno naveli, teza o Kantorowiczevu antiformalizmu prihvaćena je u teoriji prava, ali pitanje o mogućnosti svrstavanja njegove teorija $u$ skupinu kritičkih teorija prema poslijeratnom pozitivizmu ostaje neodgovoreno. Moguće naznake odgovora na to pitanje pružit ćemo usporedbom Kantorowiczevih, Hartovih i Dworkinovih stavova.

\subsubsection{Usporedba Hart - Kantorowicz}

Kriterij važenja pravnih pravila središnje je mjesto u Hartovu shvaćanju prava, a on ga objašnjava kroz teoriju o 'pravilu priznanja'. ${ }^{60}$ Pravilo priznanja je pravilo koje prema Hartu "određuje neko obilježje ili obilježja” pravila na temelju kojeg ono pripada skupu pravila. ${ }^{61}$ "Reći da je neko pravilo važeće znači priznati da je prošlo sve testove predviđene pravilom priznanja i prema tome pravilom

58 Barberis, M.; Bongiovanni, G., Neoconstitutionalist Challenges to Legal Positivism, u: LP, II. svezak, str. 243.

59 Ibid., str. 264.

60 Hart, op. cit. u bilj. 29, str. 116.

61 Ibid., str. 94. 
sustava". ${ }^{62}$ Ono postavlja standard za ponašanje nositelja pravne vlasti koji je utemeljen praksom nositelja pravne vlasti. ${ }^{63}$ Prema Hartu pravilo priznanja mora se "promatrati iz unutarnjeg pogleda na pravo kao javni, zajednički standard ispravne sudske odluke". ${ }^{64}$

Prva sličnost između Kantorowiczevih i Hartovih stavova vidljiva je u tome što obojica vezuju obilježje pravnosti nekog pravila za društvenu praksu: prvi teorijom o pravilu priznanja, a drugi teorijom o presudivosti. Nadalje, ako se Hartovo važenje pravila shvati kao pripadanje poretku na temelju nužnih obilježja koje pravilo mora imati sukladno pravilu priznanja da bi ga pravne vlasti uključujući sudove mogli primjenjivati, onda se takvo shvaćanje može uspoređivati s Kantorowiczevim pojmom presudivosti, koji on postavlja kao kriterij za opravdanje sudske primjene nekog pravila.

Prvo razlikovanje između dvaju pristupa sadržaju prava može se utvrditi ako pretpostavimo određeno shvaćanje Hartova pojma važenja. Pojam se može razumjeti kao svojstvo pripadanja nekog pravila pravnom poretku isključivo na temelju pravila koje i samo pripada pravnom poretku. Takvo shvaćanje može se izvesti na sljedeći način. Pravilu priznanja mogu se pridodati dva značenja. Ono se može odnositi na neizraženu konvenciju neke konkretne zajednice sudaca (i drugih službenika) koja ne proizvodi pravne obveze i na formulirana pravila konkretnog pravnog poretka koja proizvode pravne obveze..$^{65} \mathrm{U}$ prvom značenju pravilo priznanja je izvan pravnog poretka s funkcijom opravdanja pravnog

62 Ibid., str. 103.

63 Više o objašnjenju pravila priznanja kroz artefaktnu teoriju prava kroz koju se može odgovoriti na neka pitanja kritičara pravila priznanja vidi Burazin, L., The rule of recognition and the emergence of a legal system, Revus, vol. 27, 2015.

64 Hart, op. cit. u bilj. 29, str. 116.

65 Ovakvo razlikovanje donekle je usporedivo s razlikovanjem dviju razina postojanja pravila priznanja, koje je iznio Mathew Kramer: utemeljujuća razina i epifenomenalna razina. Kramer, M., Of final things: morality as one of the ultimate determinants of legal validity, Law and Philosophy, vol. 24, br. 1, 2005., str. 57 - 60. Prema Krameru pravilo priznanja na epifenomenalnoj razini formulirano je, primjerice, u Ustavu ili zakonu i izvedeno iz pravila priznanja na utemeljujućoj razini koje nije formulirano. Kramer smatra da obvezujuća snaga pravila priznanja na epifenomenalnoj razini ovisi o pravilu priznanja na utemeljujućoj razini i sadržaj prvog mora odgovarati sadržaju drugog. U ovom članku ističemo razliku između pravila priznanja koje pripada pravnom poretku s obvezujućem snagom i pravila priznanja koje postoji izvan pravnog poretka kao konvencija (bez obvezujuće snage). Pri tome je manje važno je li pravilo priznanja formulirano u nekom normativnom dokumentu poput pisanog ustava ili praksom sudaca. 
važenja pravila pravnog poretk $a^{66}$, dok je u drugom značenju pravilo priznanja dio pravnog poretka s funkcijom obvezivanja sudaca (i drugih službenika) što da smatraju važećim pravilima poretka.

Budući da se postojanje pravila priznanja vezuje uz stvarnu praksu sudaca (i drugih službenika), može se pretpostaviti da se prijelaz iz pravno neobvezujuće konvencije u pravno pravilo obvezujuće za praksu sudaca (i drugih službenika) nužno mora dogoditi da bi se neki normativni sustav mogao smatrati efektivnim pravnim sustavom. Drugim riječima, pravilo priznanja mora se pojaviti u njegovu drugom značenju. U prilog takvom shvaćanju može se navesti Hartovo mišljenje da međunarodno pravo nije pravni sustav jer nema pravilo priznanja. ${ }^{67}$ Formuliranje sadržaja pravila priznanja u obvezujuća pravila može se pronaći prije svega u pisanim ustavima poretka ${ }^{68}$, ali formuliranje se može postići i kroz običajno pravo sudaca. Kao što smo vidjeli iz Salmondova objašnjenja, odlučivanje sudaca na temelju općih pravila moglo se pojaviti zbog praktičnih razloga. Slično tome, možemo reći da se sadržaj pravila priznanja može uobličiti kroz stvarnu zajedničku praksu sudaca kojom na konkretnim slučajevima utvrđuju što su pravna pravila poretka i koja pravila ne pripadaju pravnom poretku. $\mathrm{Na}$ takav način kriteriji važenja utemeljeni neobvezujućom konvencijom sudaca konkretiziraju se kao pravila pravnog poretka koja pravno obvezuju suce kada odlučuju o konkretnim slučajevima. Do istog razumijevanja pojma pravila priznanja kao norme pravnog poretka može se doći i ako pravilo priznanja svedemo na norme o proizvodnji prava ${ }^{69}$ koje postoje u pravnom poretku jer su

66 Pino, G., Farewell to the Rule of Recognition?, Problema. Anuario de Filosofía y Teoría del Derecho, vol. 5, 2011., str. 285. Slično Julie Dickson navodi: “[...] because there are no validity criteria for that ultimate rule itself, no further justification of it is provided by law, and, in this sense, there are no further legal reasons justifying legal officials accepting and treating as binding the rule of recognition itself". Dickson, J., Is the Rule of Recognition Really a Conventional Rule?, Oxford Journal of Legal Studies, vol. 27, br. 3, 2007., str. 378.

Hart, op. cit. u bilj. 29, str. 236.

Guastini smatra nepotrebnim traženje bilo kakvog pravila izvan ustava koje bi opravdavalo postojanje ustava. Budući da ustav svakog pojedinog pravnog poretka određuje proizvodnju prava, faktično postojanje ustava dovoljno je za postojanje prava. Guastini, R., Sintaksa prava, Naklada Breza, Zagreb, 2018., str. 258.

"Pravila priznanja društvena su pravila kojih se zajednica pridržava prilikom identificiranja načina na koji je pravo stvoreno, promijenjeno ili ukinuto, odnosno ovo su pravila koja utemeljuju što je izvor pravno valjanih normi u danoj zajednici." Marmor, A., Philosophy of Law, Princeton University Press, Princeton - Oxford, 2011., str. 49. Waldron smatra da pravilo priznanja prima svoj sadržaj od pravila promjene koje ne dodaje ništa više tom sadržaju od sadržaja pravila promjene. Waldron, J., Who needs rule of recognition?, $\mathrm{u}$ : Adler, M.; Himma, K. E. (ur.), Rule of Recognition and 
formulirane u ustavnim odredbama ili proizlaze iz učinkovite primjene takvih pravila u praksi službenih organa.

Ako prihvatimo navedeno shvaćanje Hartova pravila priznanja, to bi značilo da se pravila pravnog poretka utvrđuju na temelju pravila unutar samog pravnog poretka. ${ }^{70} \mathrm{U}$ tom slučaju pravilo koje nije utemeljeno na postojećem pravilu u poretku može postati dijelom poretka samo na temelju promjene ustavnih odredbi ili službene prakse o tome koja pravila treba smatrati postojećim pravilima u pravnom poretku. Primjerice, ako pravni poredak sadržava pravno pravilo prema kojem pravni znanstvenici ne mogu stvarati pravna pravila, onda praksa pravnih znanstvenika nije izvor prava dok god konvencija službenih osoba podržava navedeno pravilo.

Prema Kantorwiczevim stavovima, pojam presudivost pravila može se razumjeti na način različit od navedenog shvaćanja Hartova pojma pravila priznanja. Pravilo koje nije važeće u smislu da nije proizvedeno na način predviđen pravnim pravilom unutar poretka i dalje može biti presudivo. ${ }^{71}$ Primjerice, pravila koja formuliraju znanstvenici bit će presudiva pravila ako postoji nužan i dovoljan uvjet prikladnosti takvih pravila za sudsku primjenu čak i ako u trenutku njihova stvaranja pravila pravnih znanstvenika nisu bila pravno priznata važećim pravilima trenutačnog poretka. Pravilo nije pravno pravilo zato što je važeće u smislu pripadnosti trenutačnom pravnom poretku na temelju pravila poretka. Ono je pravno pravilo tog trenutačnog pravnog poretka jer se smatra presudivim. ${ }^{72}$

Druga razlika proizlazi iz stava o praksama relevantnim za utvrđivanje pravnih pravila. Hartovo pravilo priznanja utemeljeno je isključivo praksom pravne vlasti. Dodatno, prema nekim interpretacijama Hartove teorije pravilo priznanja postoji samo kao praksa sudaca ${ }^{73}$, pa bi prema takvim interpreta-

the U.S. Constitution, Oxford, Oxford University Press, 2009., str. 341.

70 Krešić, op. cit. u bilj. 5, Primjena Kantorowiczeve i Hartove definicije, str. 122.

71 Shvaćanje Hartove teorije o pravilu priznanja u smislu primjenjivosti pravila od sudova može se pronaći kod Pina. Pino, op. cit. u bilj. 66. Pri tome, shvaćanje Kantorowiczeva pojma presudivosti navedeno u ovom članku ne može se svesti na formalni aspekt jer zahtijeva i materijalno određenje 'prikladnosti biti presudivim'.

72 Prigovor ovakvom shvaćanju pravnog pravila moglo bi biti nerazlikovanje primjenjivosti od pripadnosti pravnom poretku. Pravno pravilo drugog pravnog poretka može biti primjenjivo u prvom pravnom poretku a da mu ne pripada na temelju pravila proizvodnje. Odgovor na ovakav prigovor mogao bi proizaći iz shvaćanja samog pojama presudivosti prema kojem se svojstvo pravnosti norme određuje neovisno o razlikama između sustava iz kojih norme potječu.

73 Shapiro, S. J., The "Hart-Dworkin" debate: a short guide for the perplexed, u: Ripstein, A. (ur.), Ronald Dworkin (Contemporary Philosophy in Focus), Cambridge University Press, Cambridge, 2007., str. 25. 
cijama pravna pravila bila samo ona pravila koja priznaju sudovi. Suprotno tome, Kantorowicz ne prepušta utvrđivanje presudivosti pravila samo praksi sudaca ili praksi drugih državnih organa. Tu razliku ćemo detaljnije objasniti u sljedećem potpoglavlju.

\subsubsection{Usporedba Dworkin - Kantorowicz}

Stavovi oko nekih tema upućuju na sličnosti, ali i razlike između Kantorowiczevih i Dworkinovih shvaćanja. Prva se tema odnosi na sudsko utvrđivanje pravnih normi koje nije formulirao zakonodavac, druga na donošenje sudskih odluka suprotno zakonskim odredbama, treća na nekonvencionalni pristup izvorima prava, a četvrta na odnos prema društvenoj postavljenosti prava.

(1) Najprije, možemo primijetiti da prema Dworkinu pravo nikad ne ostaje bez odgovora jer sudac može pronaći pravni odgovor na temelju političke moralnosti i onda kada samo zakonodavno pravo to ne omogućuje. ${ }^{74}$ Naime, prema Dworkinu pravo uključuje ne samo ozakonjena pravila kao pravila koja imaju podrijetlo u pravilu priznanja nego i opravdavajuća načela. ${ }^{75}$ Nadalje, on smatra da su pravničke tvrdnje o tome što pravo zahtijeva u nekom slučaju zaključci argumenta interpretacije. ${ }^{76}$ Naposljetku, politička moralnost koja je izvor za pravne odgovore nije razdvojena od prava jer su sustavi političke moralnosti i prava sjedinjeni u jedan sustav. ${ }^{77}$

Slično tome Kantorowicz smatra da slobodno pravo omogućuje pravni odgovor za velik broj pitanja te da može upotpuniti zakonodavno pravo kad se odgovor ne može utvrditi na temelju zakona. Iako se oba autor slažu da pravo koje nije formulirao zakonodavac predstavlja važan dio prava na temelju kojeg suci mogu pronaći pravni odgovor, može se primijetiti i razlika među njima. Za razliku od Dworkina koji smatra da sudac uvijek primjenjuje pravo, Kantorowicz upozorava na postojanje situacija kada pravni odgovor uopće ne postoji jer čak i slobodno pravo ima granice. ${ }^{78} \mathrm{U}$ takvoj situaciji sudac može samo stvarati pravo, što je suprotno Dworkinovoj tvrdnji da sudac uvijek primjenjuje pravo. S druge strane, imajući u vidu shvaćanje slobodnog prava kao izvora prava, Kanto-

74 Dworkin, R., Taking Rights Seriously, Harvard University Press, Cambridge, Massachusetts, 1997., str. 87; Dworkin R., Justice for Hedgehogs, Harvard University Press, Cambridge, 2011., str. 41.

75 Dworkin, Justice for Hedgehogs, op. cit. u bilj. 74, str. 402.

76 Ibid.

77 Ibid., str. 405.

78 Kantorowicz, op. cit. u bilj. 38, str. $2011-2012$. 
rowiczevo određenje područja sudske primjene prava šire je od prostora sudske primjene prava svedene isključivo na pravila utvrđena samim pravilima poretka.

(2) Sljedeća sličnost između Dworkinovih i Kantorowiczevih shvaćanja odnosi se na mogućnost primjene prava suprotno zakonskim odredbama. ${ }^{79} \mathrm{Kao}$ što smo vidjeli, Kantorowicz smatra da sudac mora razmatrati zakone kad donosi odluke iako je i ovakva sudska praksa ovisna o konkretnim pravnim porecima. Dworkin ističe da je politička obveza poštovanja svega što zakonodavci odluče ujedno i pravna obveza jer se može tražiti njezina provedba pred sudom. ${ }^{80}$ Unatoč takvom načelnom stavu autori ipak pronalaze situacije u kojima sudac može odstupiti od zakonom formuliranih pravila. Dworkin upućuje na teške slučajeve kada postoji nesuglasnost oko utemeljenja sudske odluke, uključujući i sporenje oko neprimjene zakonskih pravila. ${ }^{81}$

Pokrovac pokazuje da je Kantorowicz revidirao stajalište od početnih stavova širokih mogućnosti contra legem odluka do sužavanja mogućnosti takvih odluka na ograničen broj situacija. ${ }^{82}$ Međutim, i kod revidiranog pristupa Kantorowicz dopušta i širi prostor za contra legem odluke ovisno o okolnostima unutar same zajednice. ${ }^{83}$ Osim toga, Pokrovac smatra da vjerodostojna interpretacija konačnih Kantorowiczevih stavova upućuje na zadržavanje teze o široj contra legem praksi sudova $^{84}$

79 Dworkin, op. cit. u bilj. 75, str. $409-411$.

80 Ibid., str. 406.

81 Dworkin, R., Law's Empire, Harvard University Press, Cambridge, 1986., str. 5, 15 -30 .

82 Pokrovac, op. cit. u bilj. 2, str. 291.

83 Ibid., str. 285. Pokrovac navodi da je u vrijeme izlaženja djela Die Contra-legem-Fabel (dalje u tekstu: Contra), glavnog rada protiv contra-legem-bajke, u tisku Rechtswissenschaft und Soziologie, u kojem (na str. 126) navodi da je pitanje otklanjanja suđenja contra legem zamršeno pitanje i može biti odlučeno samo na tlu određenih pravnih poredaka. Prema Pokrovcu činjenica da Kantorowicz nije smatrao potrebnim ukloniti ovu rečenicu upućuje na važnost koju je Kantorowicz pridavao tom stavu. Ibid., str. 285. u bilješci 1 .

84 Ibid., str. 291. Pokrovac navodi sljedeći argument u korist ove teze. Iako je djelo Die Contra-legem-Fabel posljednje djelo napisano o pitanju contra legem suđenja, Kantorowicz se nije precizno izjasnio o svim stavovima koje je prethodno iznio o takvom suđenju. Takvo prešućivanje može se tumačiti kao ostajanje pri već rečenom, a ne kao napuštanje svega što je upućivalo na zalaganje za contra legem suđenje. U pri$\log$ takvom tumačenju navodi činjenicu da je djelo Contra namijenjeno ponajprije njemačkoj pravnoj javnosti (prije svega sucima) kako bi se umirila odgovorom na kritiku navodne teze o potpunoj nevezanosti sudaca zakonom. Pokrovac zaključuje da su Kantorowiczevi konačni teorijski stavovi oni izneseni u djelu Rechtswissens- 
(3) Treća sličnost proizlazi iz njihova nekonvencionalnog pristupa utvrđivanju sadržaja prava. Konvencionalnim pristupom možemo nazvati pristup koji sadržaj prava utvrđuje: a) na temelju unaprijed postavljenog pravila unutar poretka i b) koje pravilo utvrđivanja proizlazi iz postojeće prakse službenih osoba. Kao što smo naveli, Hartov pojam pravila priznanja može se shvatiti na način kao da sadržava ta dva elementa.

Pokrovac navodi da kod Kantorowicza postoji prošireni temelj važenja prava, posebice važenja sudačkog prava, koje se ne može svesti na temelje fiksirane u zakonodavstvu. Zbog toga je prema Pokrovcu njegov model suprotan klasičnom modelu hijerarhije koji se može pronaći, primjerice, u Austinovoj ideji najviše zapovijedi i Kelsenovoj ideji najviše norme. ${ }^{85}$ Postavlja se pitanje koliko je njegova teorija o presudivosti suprotna Hartovoj teoriji o pravilu priznanja. U prethodnom smo potpoglavlju objasnili odstupanje Kantorowiczeve teorije od prvog elementa konvencionalnog pristupa utvrđivanju sadržaja prava, a u ovom potpoglavlju ćemo upozoriti na odstupanje od drugog elementa.

U nastavku ćemo razmotriti mogu li se prakse koje Kantorowicz smatra relevantnima za utvrđivanje prava svesti na postojeće prakse službenih osoba. Najprije, neki od načina utvrđivanja sadržaja prava koje navodi Kantorowicz zaista se mogu objasniti praksom službenika. Kantorowicz zakonodavno pravo i običaje dozvoljene zakonodavnim pravom smatra važećim pravom koje suci moraju uvažavati kao temelj svojih odluka u onim porecima u kojima se zakonodavstvo priznaje kao središnji izvor prava. ${ }^{86}$ Dakle, neke Kantorowiczeve načine utvrđivanja sadržaja prava možemo smatrati utemeljenima na postojećoj praksi službenika, prije svega sudaca, da priznaju takve načine stvaranja prava kao izvore prava. Ali uz pravila koja potječu od zakona i pod određenim uvjetima od običaja, Kantorowicz u sadržaj prava uvodi i pravila koja mogu potjecati od ostalih izvora pod zajedničkim nazivom slobodno pravo. Ta pravila mogu biti temelj za odluku suca iako ih zakonodavac nije prethodno formulirao. I ove izvore prava možemo djelomično objasniti postojećom praksom sudaca prema kojoj suci slobodno pravo mogu ili moraju uvažavati kao mogući izvor pravila za utemeljenje svojih odluka. ${ }^{87}$

chaft und Soziologie zajedno s raspravom o ovom djelu (Diskussion/Debatte), koji su oba objavljena u Verhandlungen des Ersten Deutschen Soziologentages vom 19.-22. Oktober 1910 u Frankfurtu na Majni. U ovom djelu i diskusiji o njemu Kantorowicz je ispravio neke ranije stavove, ali i zadržao ideju o contra legem suđenju.

Ibid., str. 384.

86 Kantorowicz ne navodi izričito razlog zbog kojeg se zakonodavstvo priznaje središnjim izvorom prava, ali takva se situacija može objasniti sudskom praksom.

Tome u prilog ide izričaj 'pravila koja se smatraju presudivima', što nas prije svega upućuje na razmatranje prakse sudaca. Međutim, potrebno je razmatrati i ostale 
Međutim, utvrđivanje prava praksom službenih osoba nije dovoljno za objašnjenje svih načina utvrđivanja prava. Moguće su situacije u kojima bi sukladno postojećoj sudskoj praksi proizašla nepresudivost nekog pravila i istodobno presudivost takvog pravila sukladno praksi za Kantorowicza pravno relevantnih subjekata. Primjerice, pravni znanstvenik može opravdano smatrati da je neko pravilo presudivo iako trenutačno ne postoji praksa sudova u kojoj bi se očitovalo isto shvaćanje. Takva situacija je objašnjiva kad se uzme u obzir da Kantorowicz utvrđivanje pravnosti pravila praksom zakonodavaca i sudaca dopunjuje praksom pravnih znanstvenika. Takvo proširenje je značajno jer omogućuje da se među izvore prava svrstaju i autoriteti koji nisu službene osobe. Međutim, Kantorowicz se ne zaustavlja na objašnjenju načina utvrđivanja sadržaja prava samo kroz praksu navedenih službenih i neslužbenih autoriteta.

Naime, možemo zamisliti da postojeća praksa pravne znanosti može biti takva da ne upućuje na pravnost nekih pravila koja bi opravdano trebalo smatrati presudivima. Vidjeli smo da prema Kantorowiczu i pravna znanost ponekad može pogriješiti kada, primjerice, ide preko granica utvrđivanja sadržaja prava. Što određuje opravdanost stavova pravnih znanstvenika o presudivosti pravila u nekoj situaciji? Već smo naznačili odgovor u prethodnim poglavljima, a ponovit ćemo ga u razmatranju posljednje teme o društvenoj postavljenosti prava. Za potrebe određenja njegova nekonvencionalnog pristupa utvrđivanju sadržaja prava dovoljno je utvrditi Kantorowiczev stav prema kojem postoje prakse izvan službenih i znanstvenih praksi zbog kojih se neko pravilo može smatrati (ne)presudivim.

Slično Kantorowiczu, Dworkin ne svodi način utvrđivanja pravila primjenjivih u nekom sporu na teoriju o pravilu priznanja. Umjesto toga, on smatra da se takvo pravno pravilo identificira na temelju opravdavajućih načela koja nisu svediva na nesporno pravilo poretka o sadržaju prava. ${ }^{88}$ Dworkinova pozicija ujedno dopušta i mogućnost postojanje pravnih pravila neovisno o sudskoj praksi. Ona postoje prije nego što je sudska praksa formulirala takva pravila, pa čak i ako sudovi donose pravila suprotna takvom pravilu ili potpuno zanemaruju njegovo postojanje. ${ }^{89}$

prakse relevantne za određenje presudivosti pravila kao što su prakse zakonodavaca i pravnih znanstvenika.

88 Dworkin, op. cit. u bilj. 81, str. 38 i 39.

89 Ibid. Marmor kritizira Dworkinov stav da je ‘ispravno pravo’ pravo čak i ako suci donose odluke suprotne takvom 'ispravnom pravu'. Vidi Marmor, op. cit. u bilj. 69, str. 91. 
Prema tome, kod obaju autora možemo prepoznati nastojanje da se objasni postojanje onih pravnih pravila koja nisu svediva na prethodno postojeće pravno pravilo o izvorima te koja mogu biti utemeljena neovisno o sudskoj konvenciji (ili konvenciji drugih službenika) u trenutačnom poretku. Takva nastojanja odudaraju od prethodno navedenog razumijevanja Hartove teorije. Odluke o pravilima koje se ne mogu izvesti iz pravila poretka o izvorima i koje nisu utemeljene konvencijama službenih organa Hart smatra stvaranjem prava, a ne rješavanjem pravnih problema postojećim pravom. $^{90}$

(4) Naposljetku, postavlja se pitanje o čemu ovisi pravnost norme koju zakonodavac i sudovi još nisu izrazili. Kantorowicz odbacuje mogućnost da se krajnja procjena presudivosti temelji na nepromjenjivom prirodnom pravu neovisnom o bilo kojoj praksi. Slično kao Kantorowicz, Dworkin također odbacuje prirodnopravnu tezu o mogućnosti postojanja pravnih pravila utvrđenih neovisno o bilo kakvoj praksi u zajednici.91

Ipak, budući da pravnost takvih normi nije nužno ovisna o postavljenim normama u poretku, kriterij pravnosti mora se potražiti u drukčijem načinu ocjenjivanja istinitosti suda o pravnosti norme.

$\mathrm{S}$ jedne strane Dworkin smatra da utvrđivanje istinitosti suda o pravnosti norme ovisi o načelima političke zajednice koja ne moraju biti, i najčešće nisu, formulirana $\mathrm{u}$ odredbe. Promjenom političkog morala u političkoj zajednici može doći do promjene istinitosti suda o pravnosti norme. Iako su jednakost i sloboda univerzalne vrijednosti ${ }^{92}$, one se konkretiziraju u sadržaj normi samo kad se primjenjuju u nekoj zajednici, i to na različite načine ovisno o razlikama političke moralnosti u različitim zajednicama. ${ }^{93}$

S druge strane, Dworkinova teza o jedinstvu etike, morala, političke moralnosti i prava ${ }^{94}$ zajedno s tezom o mogućnosti postojanja moralnih istina neovisno o praksi sudova ${ }^{95}$ upućuje na zaključak da stavovi o pravnosti norme mogu imati istinosnu vrijednost neovisno o kontingentnim praksama državnih tijela u zajednici. Njegovi stavovi o univerzalnosti načela mogli bi se interpretirati na način da bi poredak koji svojim normama uređuje odnose potpuno suprotno univerzalnim načelima o slobodi i jednakosti bio pogrešan pravni poredak neovisno o podršci zajednice takvim normama.

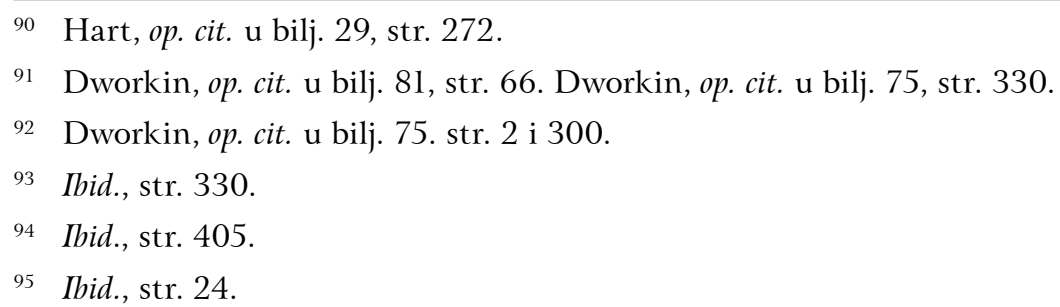


Slično Dworkinovim razmišljanjima, kod Kantorowicza nalazimo tezu o ovisnosti postavljenog prava o slobodnom pravu koje opet ovisi o stanju zajednice u kojoj se pravo primjenjuje. Ipak, kod Kantorowicza ne nalazimo tezu koja bi ga približila Dworkinovim usmjeravanjima na univerzalna načela važećima u svakoj političkoj zajednici. Istina, kada propituje dokazanost tvrdnje o uvjetovanosti prava isključivo nacionalnom poviješću, Kantorowicz kao protuargument navodi razmišljanja o postojanju univerzalnih načela. ${ }^{96}$ Ipak, svrha navoda je napad na povijesnopravnu škola koja je kritizirala prirodnopravnu školu, a nije ni pokušala obarati formalističku tezu o univerzalnim načelima.

\section{ZAKLJUČAK: TEORIJSKE I PRAKTIČNE POSLJEDICE KANTOROWICZEVE DEFINICIJE PRAVA}

U prethodnim poglavljima analizirana je Kantorowiczeva definicija prava koja uključuje pojam presudivosti. Takva definicija upućuje na poseban način utvrđivanja sadržaja prava koji se može razmatrati u svjetlu kritike pozitivizma. Kritičke teorije pozitivizma mogu se razvrstati na kritičke teorije prijeratnog formalizma i poslijeratnog pozitivizma.

Prema Kantorowiczevu pojmu presudivosti, pravo se ne može svesti na skup normi uobličenih od strane zakonodavca. Prije svega, pravo kao skup presudivih normi uključuje i norme uobličene od sudaca, što nas navodi na zaključak o Kantorowiczevu antiformalizmu. Međutim, pojam presudivosti omogućuje da se pod skup pravnih normi podvedu i norme koje ne bi bile obuhvaćene ovakvim proširenim shvaćanjem sadržaja prava. Pravo uključuje sve norme koje bi bilo prikladno smatrati presudivima od strane sudskog organa u konačnom postupku. Takvo shvaćanje presudivosti upućuje na mogućnost sagledavanja Kantorowiczeve teorije kao kritike suvremenog pozitivizma. Ovakvu smo mogućnost pojasnili na usporedbi Kantorowiczeve, Hartove i Dworkinove teorije prava.

Za razliku od Dworkina, Kantorowicz pravi razliku između stvaranja i primjene prava u sudskoj aktivnosti, ali je područje primjene zbog doktrine slobodnog prava ipak šire nego što je to slučaj kod Harta. Kada sud odlučuje sine lege, ali na temelju normi slobodnog prava takvo odlučivanje moglo bi se objasniti kao primjena prava. Isto se može reći i za contra legem odlučivanje

96 "Il est aisé de répondre que tout droit est en effet 'un droit', quo tous les hommes sont en effet 'des hommes' et qu'on peut parfaitement admettre la possibilité de principes et de catégories juridiques conformes à leur nature commune, de même qu'il est indiscutable que les hommes ont une raison et des conditions d'existence communes." Kantorowicz, op. cit. u bilj. 42, str. 9. 
(koju je tezu Kantorowicz formulirao, a prema nekim tumačenjima i zadržao do kraja ${ }^{97}$ ) ako se provodi na temelju normi slobodnog prava. Odgovor pozitivističke teorije na ove dijelove opisa sudske prakse još se može oblikovati kroz tezu o sudskom stvaranju prava. Snažnija kritika suvremenog pozitivizma ovisi o odgovorima na sljedeća dva stava o pravu. Prema Kantorowiczu, pravnim bi se normama mogle smatrati i norme koje nisu proizvedene na način utvrđen postojećim normama pravnog sustava, pri čemu način utvrđivanja pravnih normi nije utemeljen samo praksom službenih organa. Takav stav predstavlja bitnu razliku između Kantorowiczeve i Hartove teorije o načinu utvrđivanja sadržaja prava. Dok oko ovog stava postoji osnovno podudaranje između Dworkina i Kantorowicza, moguće je tvrditi da oko sljedećeg stava postoji bitno razilaženje. Oba autora odbijaju svesti pravo na društvene činjenice postavljanja normi od državnih organa, ali smatraju da je pravo ovisno o društvenoj praksi. Ako se razlika između pozitivista i antipozitivitsta svede na razliku u razmišljanju o ovisnosti obilježja pravnosti čitavog pravnog poretka o društvenim činjenicama, onda bi se razlika između Kantorowicza i Dworkina mogla tražiti s obzirom na moguće interpretacije stavova potonjeg o postojanju univerzalnih vrijednosti koje vrijede za sve poretke.

Kantorowiczev pristup utvrđivanju sadržaja prava može imati i praktične posljedice. Prihvaćanje njegova pristupa pravu može utjecati na aktivnije sudsko uobličenje onih normi koje nisu bile prepoznate u praksi zakonodavca i dotadašnjoj praksi sudova kao norme pravnog sustava. Opravdanje za takvu aktivnost nije utemeljeno na argumentu stvaranja prava, koje se sudovima često i ne priznaje, već na argumentu primjene postojećeg prava. Nadalje, uvažavanje Kantorowiczeva razumijevanja prava potiče na razmatranje stavova o sadržaju prava koje imaju pripadnici zajednice izvan službenih organa stvaranja i primjene prava, pri čemu njihova praksa prema sadržaju prava ne mora odgovarati prevladavajućoj službenoj praksi. Među neslužbenim praksama relevantnima za sadržaj prava posebno mjesto ima praksa pravnih znanstvenika. Opravdanje za presudivost takvih normi mora biti utemeljeno u stvarnom postojanju "volje, moći i prihvaćenosti" relevantnih praksi u zajednici. Navedene aktivnosti sudskog uobličavanja normi uz razmatranje svih relevantnih stavova o sadržaju prava u određenim okolnostima i posebno u određenim područjima prava, kao na primjer u ustavnom i međunarodnom pravu, može imati utjecaj na sudski razvoj pravnog poretka.

97 Vidi bilješke 83 i 84. 


\section{LITERATURA}

Barberis, M., Introduction: Legal Positivism in the 20th Century, u: Pattaro, E.; Roversi, C. (ur.), Legal Philosophy in the Twentieth Century: The Civil Law World, Springer, Netherlands, 2016., str. 181-185.

Barberis, M.; Bongiovanni, G., Neoconstitutionalist Challenges to Legal Positivism, u: Pattaro; E., Roversi, C. (ur.), Legal Philosophy in the Twentieth Century: The Civil Law World, Springer, Netherlands, 2016., str. 263-280.

Burazin, L., The rule of recognition and the emergence of a legal system, Revus, br. 27, 2015., str. 115-130.

Dickson, J., Is the Rule of Recognition Really a Conventional Rule?, Oxford Journal of Legal Studies, vol. 27, br. 3, 2007., str. 373-402.

Dworkin, R., Law`s Empire, Harvard University Press, Massachusetts, 1986.

Dworkin, R., Taking Rights Seriously, Harvard University Press, Cambridge, Massachusetts, 1997.

Dworkin, R., Justice for Hedgehogs, Harvard University Press, Cambridge, Massachusetts, 2011.

Guastini, R., Sintaksa prava, Naklada Breza, Zagreb, 2018.

Hart, H. L. A., Review: The Definition of Law by Hermann Kantorowicz; A. H. Campbell; A. L. Goodhart, The Philosophical Review, vol. 69, br. 2, 1960., str. 270-272.

Hart, H. L. A., The Concept of Law, Oxford University Press, New York, 1994.

Kantorowicz, G. U., Qu' est pour nous Savigny? Traduction français par Georges Bonnet, Paris, M. Girard \& E. Brièr, 1914.

Kantorowicz, H. U., Legal science - a summary of its methodology, Columbia Law Review, vol. 28, br. 6, 1928., str. 679-707.

Kantorowicz, H. U., Some Rationalism about Realism, The Yale Law Journal, vol. 43, br. 8, 1934., str. 1240-1253.

Kantorowicz, H. U., The Definition of Law, Cambridge University Press, Cambridge, 1958.

Kantorowicz, H. U., The Battle for Legal Science, German Law Journal, vol. 12, br. 11, 2011., str. 2005-2030.

Kramer, M., Of final things: morality as one of the ultimate determinants of legal validity, Law and Philosophy, vol. 24, br. 1, 2005., str. 47-97.

Krešić, M., Primjena Kantorowiczeve i Hartove definicije prava na medunarodno pravo, Pravni vjesnik, vol. 29, br. 3-4, 2013., str. 119-138. 
Krešić, M., Nacionalno ili međunarodno pravosuđenje kao nužan element međunarodnog prava?, Zbornik Pravnog fakulteta Sveučilišta u Rijeci, vol. 34, br. 2, 2013., str. 817-839.

Lauterpacht, H., The Function of Law in the International Community, The Lawbook Exchange, New Jersey, 2000.

Marmor, A., Philosophy of Law, Princeton University Press, Princeton and Oxford, 2011.

Pokrovac, Z., Slobodno stvaranje prava: Herman U. Kantorowicz i slobodnopravni pokret, Naklada Breza, Zagreb, 2018.

Pino, G., Farewell to the Rule of Recognition?, Problema. Anuario de Filosofía y Teoría del Derecho, vol. 5, 2011., str. 265-299.

Raz, J., The Authority of Law, Oxford University Press, New York, 1979.

Ross, A., On Law and Justice, Lawbook Exchange, New Jersey, 2004.

Salmond, J., Jurisprudence, Sweet\&Maxwell, London, 1930.

Shapiro, S. J., The "Hart-Dworkin" debate: a short guide for the perplexed, u: Ripstein, A. (ur.), Ronald Dworkin (Contemporary Philosophy in Focus), Cambridge University Press, Cambridge, 2007., str. 22-55.

Viola, F., Introduction: Natural Law Theories in the 20th Century, u: Pattaro, E.; Roversi, C. (ur.), Legal Philosophy in the Twentieth Century: The Civil Law World, Springer, Netherlands, 2016., str. 3-90.

Waldron, J., Who needs rule of recognition? u: Adler, M.; Himma, K. E. (ur.), Rule of Recognition and the U.S. Constitution, Oxford, Oxford University Press, 2009., str. 327-349. 


\section{Summary}

\section{Mario Krešić*}

\section{THE CONCEPT OF JUSTICIABILITY AND KANTOROWICZ'S APPROACH TO THE DETERMINATION OF THE CONTENT OF LAW}

Kantorowicz's concept of justiciability in his definition of law reveals a characteristic approach to the determination of the content of law. This approach can be understood as a critique of 19th century positivism as well as an approach belonging to the theories critically related to the theory of legal positivism of the 20th century. In this article, we will analyse the concept of justiciability, connect it with his broader understanding of the content of law, and explain how a distinction can be made between Kantorowicz's theory and both types of positivistic theories on the basis of this concept. Differences in relation to post-war positivism will be demonstrated through a comparison of Kantorowicz's theory with the theories of H.L.A. Hart and Ronald Dworkin.

Keywords: Kantorowicz, formalism, justiciability, sources of law, positivism

* Mario Krešić, Ph. D., Assistant Professor, Faculty of Law, University of Zagreb, Trg Republike Hrvatske 14, Zagreb; mario.kresic@pravo.hr;

ORCID ID: orcid.org/0000-0002-0014-4157 